\title{
EARLY URBAN WATER MANAGEMENT OF GDANSK, POLAND
}

\author{
Piotr J. Kowalik ${ }^{A}$ \\ Simo Lakkonen ${ }^{B}$ \\ Ziemowit Suligowski ${ }^{C}$ \\ ${ }^{A, C}$ Gdańsk University of Technology \\ ${ }^{B}$ Department of Social Science History \\ University of Helsinki
}

\begin{abstract}
This paper describes origin and development of sewer system in Gdansk, Poland, design parameters for water use and wastewater generation, gravity siphons, pumping stations, sewage fields. It was the first and complete solution of urban water on the European continent. This report gives literature review, background of decisions, comprehensive results and final conclusions. Paper focused on the water-based infrastructure in the city, namely potable water, sewerage, irrigation and drainage. Described technologies are still in use and can be used in the future in developing countries, for example for re-use of wastewater on irrigation fields.
\end{abstract}

\section{KEYWORDS}

Development of sanitary infrastructure, irrigation, sewage fields, sewer system, sustainability, urban water in Gdansk.

\section{INTRODUCTION}

Sustainability in urban water area can and will be interpreted differently by different generations. Different cultures and local circumstances will give different perspectives on those problems (Balkema et al., 2002. The sustainability assessment of waste-water systems can include: organic matter recovery, nutrients separation, low costs of water use, removing of heavy metals and bacteria, land use for constructed wetlands and pond systems. Sustainability is interpreted here as the minimum energy consumption, use of materials of local origin (bricks and stoneware, efficient treatment of wastewater on sewage fields, with possible re-use of treated water (Otterpol et al., 1997. Urban water management is a main focus of this paper.

Kowalik and Suligowski (2001 wrote that "according to the concept of sustainable development, every community should function without degrading natural resources and ecosystems, and the technologies employed should have positive impact on nature and society. Sustainability in water supply and sewerage systems requires completeness, universality, a systems approach and a high standard of reliability". 
These authors indicate that "completeness" means that the requirements of the quality of drinking water and the utilization of human waste are met. "Universality" entails that the system serves all inhabitants without discrimination and that the system is made according to the best available technology. "A system approach" means that all the needs of the inhabitants are met in terms of quantity and quality of water and that all wastewater is taken from the city and treated without negative effects on the recipients. The high "reliability" standard means that the system should function well without interruptions (Kowalik and Suligowski, 2001. We discuss and conclude the sustainability of the $19^{\text {th }}$ century solution following and enlarging the short synopsis published by Kowalik and Suligowski (2001.

\section{IMPORTANCE OF HISTORY}

Significant changes in nature take generally place over long periods of time. Hence we need historical perspective to understand when, why, how and where major changes occur in our environment. Accordingly major changes in societies take place over long periods of time. Hence we need historical approach to understand significant changes in human ideas and practices as well. Environmental history tries to connect these two approaches in order to describe and explain how and why major changes in nature-human relationship have occurred.

In the Baltic Sea Region a major challenge is to understand how the contemporary pollution and protection of this regional sea area have emerged. To understand the formation of contemporary technical system of water protection we need to explore the history of urbanindustrial wastewater treatment. Due to the lack of previous historical studies we cannot explore the history of the whole wastewater treatment systems that consists of thousands of treatment plants in the region. Instead we focus on the following crucial question. How, when and where waste water treatment was started in the Baltic Sea Region?

Answering this question is of high importance as such knowledge would provide a much needed concrete base for future studies that could then focus on the development and diffusion of wastewater treatment technology on regional, national or international level. Such extensive studies are, however, beyond our resources.

We conducted previous studies in an international project entitled "The Sea and the Cities" that explored the history of urban water protection in the Baltic Sea region. According to the results of this project the first modern wastewater treatment in the Baltic Sea Region was constructed in Gdansk in late 19th century. Hence we made a case study of this plant in order to explore the following questions. Who planned and built this pioneering wastewater treatment plant? What were its main components/structures and processes?

We will investigate historical records and materials to answer the questions. In order to understand the context of building the wastewater treatment plants we will explore the development of the supply of drinking water, i.e. the whole water supply system. Past technologies may often seem from today's point of view old fashioned, outdated or nonefficient. Therefore we will also interpret the function and efficiency of the first wastewater treatment plant in the Baltic Sea region from contemporary point of view, by means of criteria of sustainable development.

The publications on history of urban water are very limited. The new review was given by Seeger (1999 for German solutions. He indicates that wastewater management was connected 
to the rapid industrialization and urbanization during the second half of the $19^{\text {th }}$ century, related to the rise in population in European cities. In Gdansk the population was 64000 inhabitants in 1849 and the people were employed mainly in army as a soldiers (up to $10 \%$ of population and in the state administration. Population growth was in 1875 up to 98000 , in 1905 up to 160000 and in 1914 up to 175000 . The city of Gdansk in 1800 was the fourth biggest city of Germany (after Berlin, Breslau and Königsberg, but in 1910 it was only nineteenth in Germany (Cieslak and Biernat, 1994. Much bigger were Hamburg (650 000 in 1900, Munich (500 000 in 1900 or Leipzig (455 000 in 1900 (Seeger, 1999. Importance of Gdansk in Germany was because of harbour, exporting grains and timber and because of the location of navy ships. During the period 1850 -1917 in Gdansk was produced 65 big military ships for German army (about one war ship per year. In the period 1914-1918 Gdansk became the centre of the production of German sub-marine boats in great amount.

Seeger (1999 wrote that were several epidemics in the cities, causing numerous deaths. Two vital waterborne diseases in this period were typhoid and cholera. Cholera only occasionally occurred and in limited areas, in 1831 for the first time in Germany. In Gdansk in 1831 as a result of cholera epidemics was dead several hundreds of people (Cieslak and Biernat, 1994. In 1866/67, a massive wave of cholera epidemics spread over the whole Germany. Typhoid, on other hand, has a permanent presence in the cities, and it continued to show mortality rates up to the late $19^{\text {th }}$ century.

The idea was accepted that the cause of the epidemics had to be looked for the cities' bad sanitary conditions. According to Seeger (1999 the studies done by Max J. Von Pettenkofer, who was Ordinarius for sanitation in Munich 1866-1894, contributed in particular to the acceptance of this idea. One of the main prerequisites for improving the sanitation of the cities was the save drinking water supply and efficient removal of the waste water. In London doctor John Snow in 1854 was investigated that the well for water supply was a main source of the epidemic disease in the city (Hultman, 1992.

It would be a highly interesting question to study why the first wastewater treatment plant was built from political point of view. Unfortunately almost all archival material of municipal administrational bodies of Gdansk was destroyed during wars. Many questions are not answered, for example why Gdansk seems to be a special case in terms of water protection? Why the city started to act and why it initiated wastewater treatment so early, in 1872 ? Policies and strategies of water management must be identified and described, but the historical sources are very limited.

The main reason of the activity in Gdansk urban water management was population growth, epidemics, bad smell, infrastructure of harbour and military needs of navy.

\section{ORIGIN OF THE SYSTEM}

Beginning of the modern water supply and sewer system of Gdansk, Poland, occurred in second part of $19^{\text {th }}$ century, during the period 1869-1872. The idea of the central systems of urban sanitation started in the middle of $19^{\text {th }}$ century in England and Germany. The reason of the development was because of the epidemic catastrophes in the bigger cities of Western Europe. In Gdansk such epidemics were quite frequent during $16^{\text {th }}$ and $17^{\text {th }}$ centuries. Here were introduced the preventive systems related to harbour and the city by quarantine. 
The inhabitants were responsible for the investing decisions for central water supply and sewer system and the knowledge about sanitation was distributed in many cities.

The systems constructed in the middle ages for water supply by aqueducts and the dry toilets for waste were present till 1869. Modern solutions were invented in Great Britain and replicated in the continent during the second part of $19^{\text {th }}$ century. The prototype of the urban sanitary solution was constructed in Great Britain. It was a reason that in year 1860 German Ministry of Trade decided to send to Great Britain three German experts: Wiebe, Hobrecht and Veitmayer. They studied existing solutions and were designers of many German infrastructural cases. The solution for Gdansk was prepared by mentioned experts as a pilot system for central water supply and central sewer system for wastewater utilization.

The first solution of water supply and waste water utilisation was constructed in Gdansk during year 1354 for the city with 8000 inhabitants. The idea was born in mind of the Teutonic Knights who constructed the castle of Gdansk and walls around the city. It was necessary to construct the water supply by the open water channel from River Radunia and located this channel on the elevation of $6 \mathrm{~m}$ above sea level at the bottom of moraine hills on the distance of $10 \mathrm{~km}$. This channel exists till today and had two goals: water supply and energy source for the mills in the city. Water was taken from the sides of the channel in the city by special underground water supply system made from wooden pipes with lead joins. Water was flowing from the channel by wooden pipes to special vertical containers similar to wells. These wells were distributed in the city in the yards or in the basements of the houses. It was more than 600 such wells-containers. Water was taken by buckets by individual users for drinking, cooking, washing, laundry and cleaning of houses.

Wastewater was flowing to the open ditches in the middle of the streets, but these ditches were lined by wood and covered by the special wooden boards as the pavements for pedestrians. Wastewater was dumped to the River Motlawa in the middle of the city. In the similar way was dumped the water from surface runoff by open ditches as a gutters, existing even till today. Every house was equipped in the dry toilet were the waste was transported outside of the city few times during the year. The system was not efficient to prevent epidemic diseases. Many times the city was described by different authors, but in most cases the "bed smell" was very often mentioned. Seeger (1999 indicated that although streetdraining facilities existed in most cities, they were not designed to handle the high quantities of waste water produced in the densely populated cities of the late $19^{\text {th }}$ century. Thus the construction of sewer systems became necessary. The stone pavements were invented in the centre of Gdansk in 1874.

\section{DEVELOPMENT OF THE SEWAGE SYSTEM}

In the history of Gdansk the period of 1869-1872 was dominated by the construction of sanitary infrastructure in the densely populated centre of the city of Gdansk (98 000 inhabitants in 1875. The wastewater treatment plant was the sewage fields in Gdansk-Sianki (constructed during 1871-1872.

During the second part of the $19^{\text {th }}$ century many sewer systems were constructed in the bigger cities of Germany (Brix et al., 1934. Sewer construction in German cities were: Hamburg 1842, Frankfurt 1867, Stettin 1868, Gdansk (Danzig 1871, Berlin 1873 (Seeger, 1999. 
Sewage fields for wastewater treatment were constructed in Gdansk (Danzig in 1871, Berlin in 1873 or 1878 (Hahn and Langbeim, 1928, Freiburg around 1890, Darmstadt around 1890 (Seeger, 19999. Surface are in Gdansk (Danzig was 320 ha, in Bremen 400 ha in 1877, in Wroclaw (Breslau 1778 ha in 1881, in Berlin 12300 ha in 1884, in Königsberg 800 ha in 1899.

Development of the city is depicted in Fig. 1, showing the situation in year 1900, in year 1939 and in the year 2000. The unique solution of Gdansk was because here the central water supply system, sewers and central waste water treatment plant were made in the same moment, first time in the European continent. The rule was to connect all existing buildings in the city to water supply and sewer collectors. Such connections were constructed for 3887 houses in the city. During dimensioning of the system was assumed that the population of the city is equal to 100000 inhabitants and water consumption and wastewater production was taken as 100 litres per person and day. The real consumption was 70 litres per person and day in 1900 and the inhabitants 160000 in 1905.

Decisions on the construction of sanitary infrastructure were not easy and related to many technological limitations. It was not cement production. Energy supply of pumping stations was related to the steam engine utilisation, fuelled by wood, coal or biogas. New materials and electricity was invented only at the beginning of $20^{\text {th }}$ century. As a result of the limited energy supply was the location of the water intake in Pregowo $120 \mathrm{~m}$ above sea level and 14 $\mathrm{km}$ from the city with gravitational water flow by main pipe $\varnothing 418 \mathrm{~mm}$ and capacity 10000 $\mathrm{m}^{3} /$ day.

Construction of sewer system allowed to close all try toilets in the city and to make order with the surface run-off of waste originated from rain precipitation. Only in the far located suburbs the dry toilets and open ditches for run-off were existing until the end of $20^{\text {th }}$ century. Water supply from the central system was under the control of the quality of drinking water. City authority was involved into the quality control. As a result few pharmacies in Gdansk were appointed to carry out the measurements of drinking water and wastewater quality in 1870 ' and 1880'. Two persons were responsible for this monitoring - medical doctor Albert Liévin and pharmaceutical chemist Otto Helm, owner of the pharmacy shop "Apteka Polska" (Helm $1875 ; 1881$. 

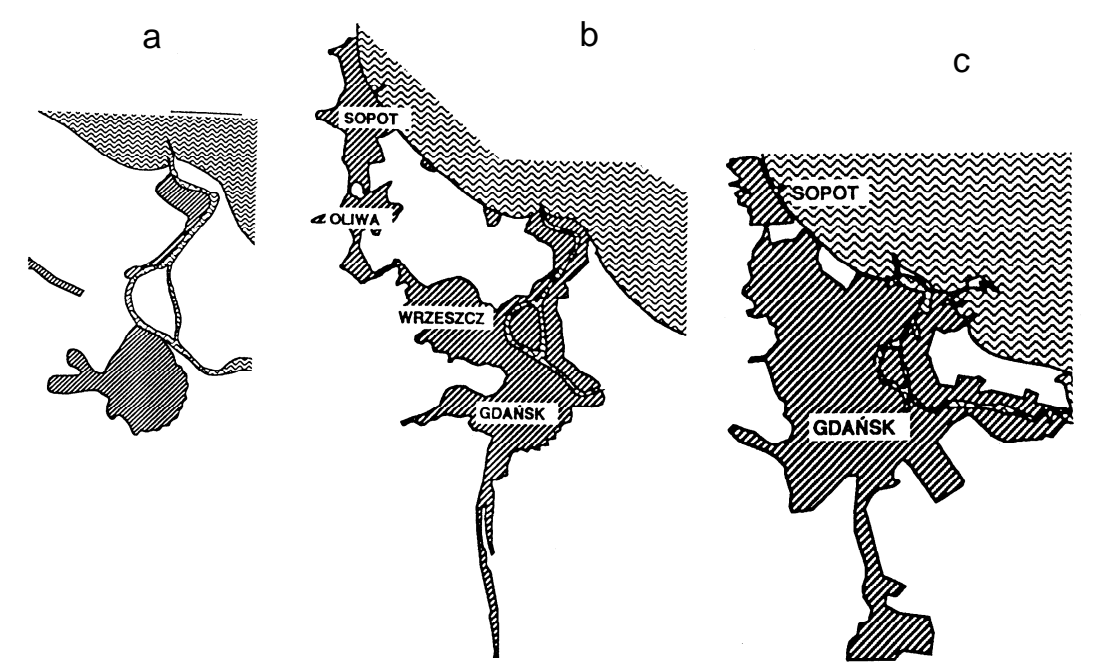

Fig. 1. Urban development of the city of Gdańsk: a-year 1900; b-year 1939; c-year 2000.

Authors of the system design were E. Wiebe (railroad engineer and L.A. Veitmeyer (building construction engineer. Big support was given by Baldwin Latham, President of the Society of Engineers in London. He was not only the consultant, but the author of many detailed solutions. Great importance was work of the experts in geodesy and cartography and members of the City Council - Moore, Kischke and Licht. Licht was responsible for the quality control of constructions and for many detailed works.

Construction works were quick and proper. It was mentioned that Wiebe and his co-workers visited Great Britain to study British solutions. Wiebe made a report after this tour and prepared the concept of the wastewater treatment plant for Berlin during 1860. After coming to Gdansk he initiated the geodesy survey, completed in 1863. Design of the sanitary infrastructure was prepared and printed in the form of book during 1865 (Wiebe, 1865. This project was distributed among the Members of the City Council for discussion and evaluation and positive decision was taken during 1868.

The contract was negotiated and the Berlin Construction Company Aird was accepted by the city of Gdansk. The name "Aird" is very typical Scottish. This Aird Company decided to move to Gdansk for the next years. The negotiations on the water supply system was completed in 1869, the negotiation on the sewer system was completed in 1870. After long period of negotiations and preparations of the construction (1865-1868 in City Council, 18681870 to complete contracts the realisation was very quick and good. Water uptake for water supply system was ready in 1869, all the underground pipes for water and wastewater were ready in 1871 and the wastewater treatment plant as a sewage fields was completed at the beginning of 1872 . It is important to stress that it was not so many bureaucracy these days. Many investments started earlier than the official contracts were made, for example the earth works on the water uptake plant in Pregowo started in 1865 (contract in 1868, and in GdanskSianki in 1869 (contract in 1870. 


\section{SPECIFIC CHARACTER OF THE GDANSK SEWER SYSTEM}

\subsection{Design parameters}

First concept of the sewer system of Gdansk was implemented to the common system with run-off and sanitary wastewater all together. But just from the beginning the amount of rain water directed into the sewer was very limited, because most of run-off was flowing by the open ditches in the pavements of the streets. Curious case was that the dimension of the sewer was very small, below $\varnothing 381 \mathrm{~mm}$, and the length of the collectors was very short, limited to the surface area of the old city centre. The idea agreed with the recent concept that the intervention in the natural conditions of run-off should be minimal.

Sewer pipes were located under the ground with relatively small slopes and the flow should be quite intensive in such a case. It was necessary to plan the intensive exploitation of the sewer and it was assumed that the washing of the pipes should occurred every 3 weeks, but in practice the washing activity was performed every 1-2 moths. During the periods of no rain the source of washing water was the local Radunia River in the city. Water was directed into the washing sewer wells and about $9 \%$ of the inspection chambers (control wells were used as washing wells. It was dependent upon the elevation of the terrain. In the upper parts of the city only $1 \%$ of the inspection chambers were used for washing of the sewers, in the old city it was about $9 \%$, but in the lowest part of the city it was 33\% of the chambers used for washing of the sewers.

All wastewater was collected by gravity to the main pipes and sent to the central pumping station of the Island Olowianka. Flow to the island was possible by two siphons under the bottom of the Motlawa River. The dimension of these siphons was $\varnothing 470$ and $\varnothing 710 \mathrm{~mm}$. From pumping station the wastewater was send by the pressure pipe with diameter $\varnothing 575 \mathrm{~mm}$ and the length $3 \mathrm{~km}$ to the sewer fields for wastewater treatment. At the end of the pressure pipe was constructed special brick chamber for reduction of the pressure. The next step was primary settlers for sewage sludge and after sedimentation here the wastewater was used for irrigation of grasslands on the area of 320 ha.

The first sewer system of the old city of Gdansk was constructed during the period 18691871. In the same time before 1880 the sewer system was constructed in the new suburb of the city in Gdansk-Wrzeszcz, West direction from the old city. This new suburb was intensively constructed before the end of $19^{\text {th }}$ century, up to 35000 new inhabitants.

Danger of flood was present in the old city from the Vistula and Motlawa Rivers, connected to Baltic Sea. Main reason of the flood was changing level of sea water in Baltic because of the wind storms from the North. For protection against high water from the Motlawa River the special trap-doors and gates were constructed. At the end of the sewer and in the location of the outlets of the pipes into the river special trap-doors were installed with weight-driven closings, partly open during heavier rains and locked during the periods of the higher levels of water in the river. This system was recently neglected and substituted by the local pumping stations, working during the periods of the higher water in the river. 


\subsection{Main pipes of the sewer system}

Most of the old sewer system was constructed from the stoneware pipes with diameter $\varnothing 229$ $\mathrm{mm}(85 \%$ and bigger $\varnothing 305 \mathrm{~mm}(15 \%$. Slopes of the pipes were quite low, equal to $0.0004-$ 0.0007 , and during the excavations the ditches were not dewatered because the water was not flowing from outside. The skills of the workers were very high, because even today the slope equal to 0.001 is difficult to obtain. The distance between inspection chambers (control wells in the sewer system was large, up to $100 \mathrm{~m}$ between the wells. From the point of view of the recent standards such large distance was possible only if the construction was very precise and the exploitation was very proper and timing.

During the excavation of the ditches for pipes of sewers only possible technology of dewatering was limited to the boxes filled by gravel and located in the bottom of the ditches and local shallow wells. All the works were done by hand, without any machinery, and the safe depth of the ditches was defined up to $3 \mathrm{~m}$ below the ground. This depth was up to $4 \mathrm{~m}$ and in some parts of the old city it was even $5 \mathrm{~m}$, but this was $1 \mathrm{~m}$ below the ground water level. It was only in few locations. The most difficult point was in the Street Kotwicznikow, were the wide of the street was $3.7 \mathrm{~m}$ and the depth of the ditch for the sewer pipe was on the level $4.4 \mathrm{~m}$ below the ground.

The city had the bed opinion because of the odours in the streets. To avoid odours from the sewer system the control wells were equipped with the special active-coal-filters, according to the system invented by Rawlison in Great Britain. The big curiosity of the system was related to the special washing of the sewer. At the outlets of the sewer to the rivers were constructed special gates, open for washing and closed during the higher levels of the water in the sea and in the rivers.

\subsection{Main collectors of sewer system}

Main collectors were taking wastewater from the stoneware pipes. Main collectors were constructed in brick with the cross section of the shape of egg. Dimension of the channels were $1020 \mathrm{~mm}$ (width and $1530 \mathrm{~mm}$ (height. The proportion between width and height was like 1: 1.5 and it is applied in such systems till today. The total length of the main brick collectors was only $6 \mathrm{~km}$. It was about $2.5 \mathrm{~km}$ in the main city, about $1 \mathrm{~m}$ in the oldest city and about $2.2 \mathrm{~km}$ in the Lower City. The slopes of the channels were 0.0007 in old and main city and in the lowest part of the city only 0.0004 (main city and lower city. Relatively large collectors were designed according to the idea of the protection against flood in the city, for the quick dewatering of streets in the case of flood. Main brick collectors were founded on the gravel sub-crust, or the foundation was made from the concrete, which was not invented yet in most cases and it was necessary to make very detailed introductions how to use concrete at all, for example in the book of Wiebe (1865.

\subsection{Siphons}

In the sewer system of the city of Gdansk two siphons were constructed, working by gravity. Location of the siphons was $4.7 \mathrm{~m}$ below the main water level in the river. In the inlets into siphons were constructed special sand traps. Gravity construction made for Gdansk was described and published and was a subject of many replications in many cities later on. 
Wastewater was collected in the Island Olowianka and by pumping station was sent to the sewage fields in Gdansk-Sianki. The pressure pipe was $3 \mathrm{~km}$ long. This pipe was located below the River Motlawa. It was another siphon, working as a pressure pipe. Diameter of the siphon was $\varnothing 575 \mathrm{~mm}$, length $145 \mathrm{~m}$ and located $7.7 \mathrm{~m}$ below the level of the water in the river.

\subsection{Main pumping station Olowianka}

Main pumping station Olowianka was designed in 1865 as a main element of the sewer system and was used by few generations later on. Just from the beginning the capacity of the pumping station was quite large, because the station was designed not only to pump wastewater but to supply water for washing of sewer system and to allow quick dewatering of the streets in the case of flood. Pumping station was responsible for the relatively high speed of flow in the sewer pipes.

The construction included two doubled piston pumps with steam engines. Diameter of every pump was $\varnothing 0.51 \mathrm{~m}$ and feed (slide of piston was $1.07 \mathrm{~m}$. Capacity of the pumping station was between 60 and 520 litres per second and the pressure head was $12.5 \mathrm{~m}$. It was sufficient for the proper work. Power of the steam engine to run the pumps was from 6 to $40 \mathrm{HP}$ (4.5 $30 \mathrm{~kW}$. Two engines were constructed with the power of $35 \mathrm{HP}$ (about $26 \mathrm{~kW}$ for every engine. Working together it was about $40 \mathrm{HP}$, but additional engine and additional pump were able to increase a capacity much more. At the beginning the fuel was black coal, but later on was possible to use the gas, used for lighting the streets or biogas from the fermentation of sewage sludge. Close to the pumping station was constructed high chimney, existing till today. In the engine station was constructed two boilers in Galloway system. In the normal conditions only one boiler was working with the sufficient capacity.

Main pumping station was working from 1870 to 1970 but exists till today, for example original building and chimney, like in the middle of $19^{\text {th }}$ century. Recently the electricity supply needs different building, but the old one is in very good shape, well protected.

\section{ACTUAL STATE OF THE OLD SEWER SYSTEM}

The design was made during 1863-1864, more than 140 years ago. The system contains main brick collectors and stoneware pipes. They are working well in actual conditions. In use are two gravitational siphons directing wastewater from the city to the main pumping station. From 1900 in Gdansk were constructed only separated sewers, different for rain water and separate for sanitary wastewater. The state of the pipes and inspection chambers is very good, much better than the newer elements of the system. Only one problem is clear. After separation of sanitary wastewater from rain-water and neglecting the frequent washing of the system - the odours are generated locally but not frequently.

Sewer system for rainwater is not working very properly. During $19^{\text {th }}$ century were much more open waters in the city, partly related to the military fortifications. After the beginning of $20^{\text {th }}$ century several open water bodies in the city were liquidated and the natural equilibrium of the catchments disappeared. Recently the level of the ground water is too high in the lower part of the city. The sanitary system was developed, but the system of the dewatering of the city after heavy rains is not solved properly yet. 
Sewer system of Gdansk is old, first on the European continent. It was the reason, that the system was described in the publications, in $1860^{\prime}$ it was 3 publications, in $1870^{\prime}-14$ publications, in 1880' - next 9 publications. It was reproduced in well known journals during these days. The publication of the design (Wiebe, 1865 in the form of book was very well known in the society of engineers. It is necessary to stress that the origin of the system was dedicated to the city with 100000 inhabitants in the town which was a military fortress.

\section{FIRST WASTEWATER TREATMENT PLANT IN GDANSK-SIANKI (SEWAGE FIELDS}

The first wastewater-treatment plant consisted of the irrigation fields of Sianki (in German: Heubude. The sewerage systems were completed in 1869-1871 and the wastewater treatment plant was constructed in 1872, three $\mathrm{km}$ from the city. This consisted of the 180-320 ha of the irrigation fields. These fields were never used for agriculture and have always served as a phytotechnological treatment plant till 1994. In the original plans the surface area of 600 ha was expected, but later on it was reduced to 180 ha in 1872 and 320 ha at the beginning of $20^{\text {th }}$ century (Salomon, 1907; König and Lacour, 1914.

Sand dunes were described by Stremme (1942. The ground was levelled and ditches were constructed on 2 levels. Ditches on the upper level received municipal wastewater, those at the lower level served to drain treated wastewater. From the upper ditches wastewater was distributed to flood and irrigate sandy soils covered by grass. The construction is depicted in Fig. 2 and Fig. 3. Frequency of flood was mainly every week and the total hydraulic load was $3000 \mathrm{~mm}$ per year during 100 years, but after 1970 hydraulic load increased to $8000 \mathrm{~mm}$ per year.

Fields in Gdansk-Sianki were covered by grass monoculture for hay production of couchgrass (Agrophyron repens L. and in the locations of local sedimentation of sewage sludge the monoculture of nettle (Urtica dioica L. was developed. Soil profile was greatly changed under the influence of the wastewater irrigation and under the change of the water conditions of soils. Evolution of soils started from the pure sandy dunes, changing to forest podzols, sod covered podzols with gley formation in subsoil, rich in organic matter shallow boggy black earths and ending with shallow peat soils on the gley sandy subsoil. This evolution of soil profiles was generated by the regulation of water conditions in the fields. Dune soils were utilized for the irrigation of wastewater of the city of Gdansk and wastewater treatment in soil environment. It started during spring 1872. They were the first soils irrigated by city wastewater on the European continent. 


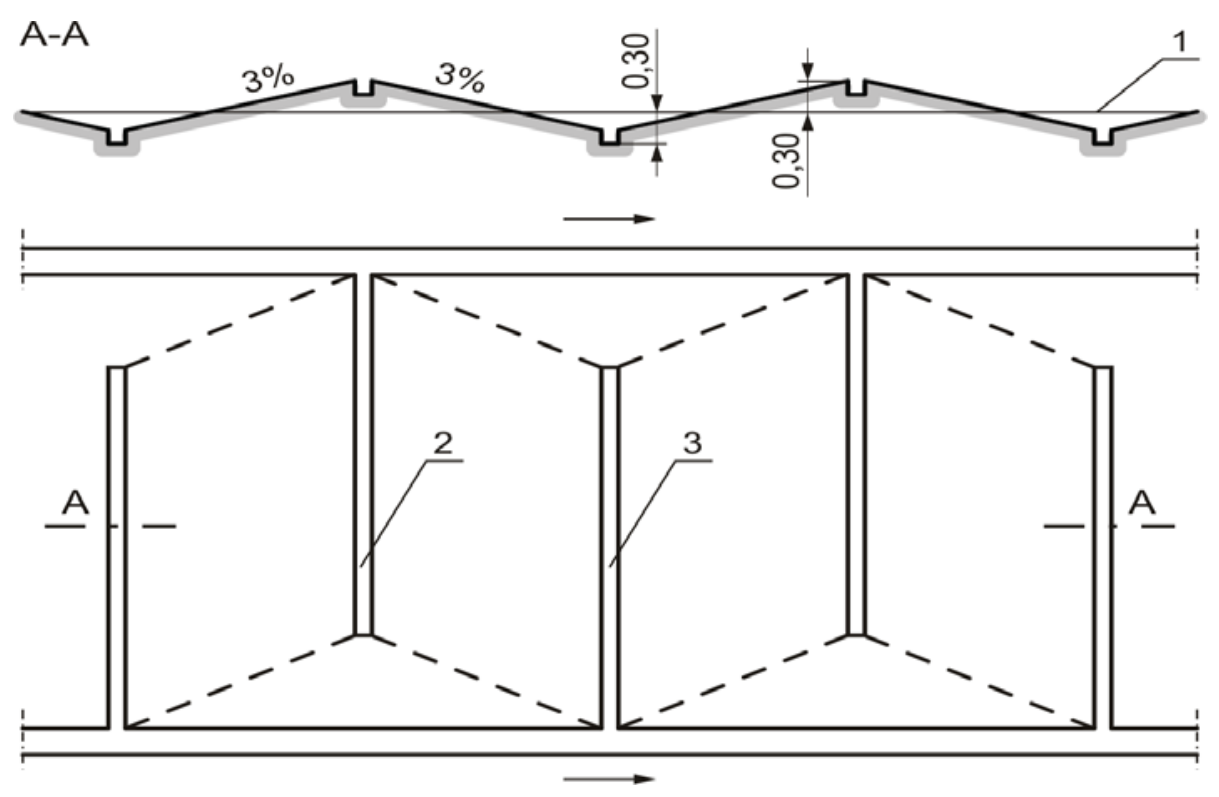

Fig. 2. Irrigation system with flood of the fields on the artificial slopes. 1 -original level of the ground; 2 -ditch for irrigation by wastewater; 3 -ditch for drainage of treated wastewater (Woycicki, 1956.

During years 1869-71 pine forest was cut, dunes were levelled and ditches for wastewater flow were constructed. At the beginning of 1872 only 180 ha were utilized, but in the next years additional 120 ha were included, ending with 320 ha at the beginning of twenty century. Hydraulic load can be calculated, dividing the amount of wastewater $\left(10000 \mathrm{~m}^{3} /\right.$ day by the surface area of the fields (360 ha. During 1912 the hydraulic load of the field was $3300 \mathrm{~mm}$ per year, during the year $1958-3650 \mathrm{~mm}$ per year and in $1972-8000 \mathrm{~mm}$ during the year. Most of the wastewater was treated only in the sedimentation basins. Irrigated fields were dewatered only by the open ditches. Treated wastewater was dumped into Vistula River outlet close to the Baltic Sea.

On the dune sands after irrigation of wastewater the succession of grass vegetation was observed and formation of sod layer. Instead of forest podzolic soils were created grassland sod soils with shallow gley formation. After intensive irrigation the ecological and hydraulic situation was changed. Formation of grass and sod in topsoil was stimulated by frequent wastewater irrigation and formation of gley subsoil because of anaerobic conditions and lack of oxygen diffusion from the atmosphere. Old process of podzolisation was dominated now by the process of sod formation. Vegetation consisted of grass, intensively and frequently irrigated by wastewater. 


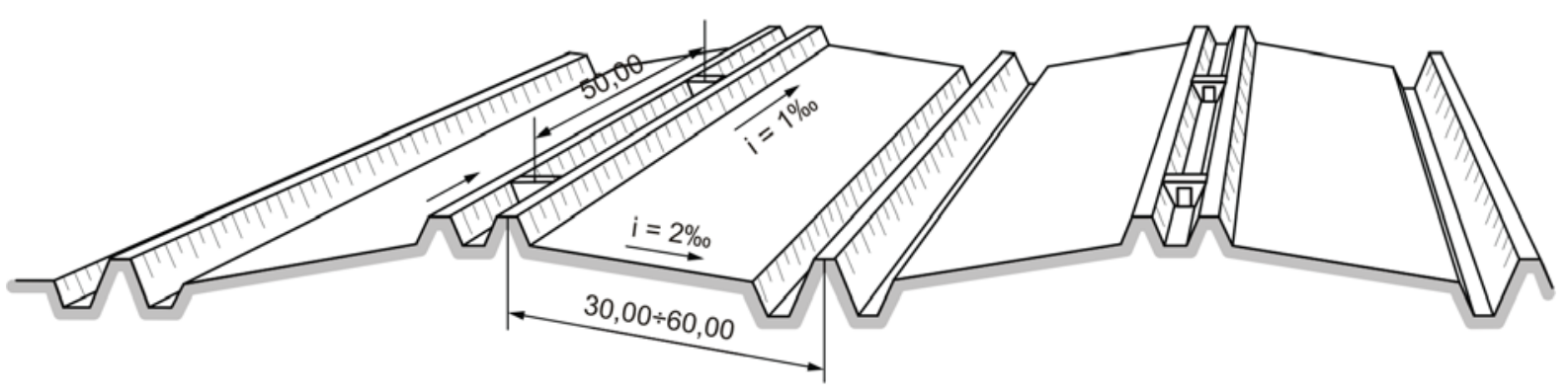

Fig. 3. System of irrigation and drainage of the fields in Gdansk-Sianki.

Such soils cover at least $1 / 2$ surface areas of the irrigated fields, but only if the drainage ditches are working properly and the altitude are high. They were used as mowing grassland, to produce hay twice a year. If the ground water level is close to the surface and soil is very rich in organic matter from wastewater, the oxygen balance is negative. Lack of oxygen is giving shallow gley layer in soil and succession of the hydrophilic plants, natural for wetlands. Instead of natural grasses appear grasses producing tufts and clusters and sedge (Carex. The domination of wetland conditions occurred on the half of the surface area of the Gdansk soils irrigated by wastewater. Part of the soils was ponded, or changed in the wastewater lagoons with the vegetation of wetlands. The soil profiles were changed into direction of bog areas.

In the case of sewage fields in Gdansk (Poland it is visible that the soils were overloaded by high hydraulic load of wastewater, from $3000 \mathrm{~mm}$ up to $8000 \mathrm{~mm}$ per year. This was the reason for the creation of the conditions of wetlands. The efficiency of the wastewater treatment in this ecosystem was about $80 \%$. The phytotechnological solution was serving here during 120 years (1872-1994 and it was a good and efficient example of utilization of soil for protection of Baltic Sea. In the last 15 years (1994-2008 was no irrigation and drainage here. The technology belongs to the past (Kowalik and Suligowski, 2008.

\section{CONCLUSIONS}

History of sewer system in Gdansk, Poland, is good lesson on the sustainability in the past, around years 1869-1871. During this period it was no electricity, no concrete or plastic constructions, no activated sludge reactors, and lack of many others modern solutions. Sustainability was interpreted as the minimum energy use, use of materials of local origin (bricks and stoneware, and efficient treatment of wastewater on sewage fields, with possible re-use of treated water.

The old structures survived for one century are the example of the holistic thinking and the proof that a sustainable city should have an infrastructure that is capable of serving several generations. Urban water system is mainly extensive, costly, public, centralized, difficult to modify and designed to remain in service for at least several generations. The sanitary infrastructure of a city can be seen as the largest machine constructed by human beings.

Sustainable development has many dimensions, including functional, environmental and social-cultural aspects. It is difficult to obtain clear indicators for sustainability assessment. Anyway several indicators are proposed by Balkema et al. (2002: 
- organic matter and methane recovery may be essential for sustainable wastewater treatment;

- nutrients and urine separation may be essential for sustainable sanitation;

- low cost of water supply and wastewater treatment must be obtained;

- the ability to remove heavy metals and bacteria is necessary;

- cheap land area for some technologies, like wetlands and ponds are needed.

From these indicators the solution of Gdansk was able to separate nutrients and organic matter from waste water on sewage fields to produce grassland and hay. The sewer system was working mainly because of gravity, with low cost of maintenance. The concept of wetlands and ponds was implemented. Removal of heavy metals and bacteria was not efficient. Recovery of methane from sewage sludge was efficient to run the wastewater pumping station in the city, but only in very short period of time.

Consideration are indicating how the system was invented, constructed, modernized and developed over time, taking into account the process of ageing. Public opinion is still aware of the age-old idea that the system should bring clean and safe drinking water and remove all kinds of wastes from the city. Accordingly, supply and dumping are the main activities, instead of preventing water pollution or closed recirculation of water or waste for re-use again and again.

Recent population of 500000 people in the city needs new solutions, very different from $19^{\text {th }}$ century concepts. Anyway the old part of the sewer system is serving perfectly after 140 years of existence.

\section{REFERENCES}

[1] Balkema A.J., Preisig H.A., Otterpohl R., Lambert F.J.D., 2002. Indicators fort he sustainability assessment of wastewater treatment systems. Urban Water 4:153-161.

[2] Brix J., Imhoff K., Weldert R. (eds), 1934. Die Stadtenwässerung in Deutschland, Gustav Fischer Verlag, Jena.

[3] Cieslak E., Biernat C., 1994. Dzieje Gdanska (History of Gdansk). Fundacja Rewaloryzacji Gdańska, Gdansk (in Polish).

[4] Hahn H., Langbeim F. (eds), 1928. Fünfzig Jahre berliner Stadtenwässerung 1878-1928, Alfred Metzner Verlag, Berlin.

[5] Helm O., 1875. Über die chemische Beschaffenheit der Kanalflässigkeit und des Abfluss wassern der Danziger Rieselanlagen (The chemical composition of the wastewater treated on the irrigated soils in Gdansk). Der 48 Naturfoprscherversammlung, Graz (in German).

[6] Helm O., 1881. Chemische Analyse des Abwassers der Danziger Riesenfelder (Chemical analysis of the wastewater on irrigated soils in Gdansk). Schriften der Naturforscherversammlung Gesellschaft in Deutschland, Ad. V (In German).

[7] Hultman B., 1992 Water and wastewater management in the Baltic region. Uppsala University, The Baltic Sea Environment, Session 9, Uppsala.

[8] König J., Lacour H., 1914 Die Reinigung städtischer Abwässer in Deutschland nach den natürlichen biologischen verfahren. Landwirtschaftliche Jahrbücher, 47:478.

[9] Kowalik P., Suligowski Z., 2001 Comparison of water supply and sewage in Gdansk (Poland in three different periods. Ambio 30(4:320-323. 
[10] Kowalik P., Suligowski Z., 2008 Effect of wastewater irrigation and drainage on soil properties of sewage fields of Gdansk (Poland). In: Proceedings of the $10^{\text {th }}$ International Drainage Workshop of ICID Working Group on Drainage. Helsinki University of Technology, Helsinki, 6-11 July 2008.

[11] Otterpohl R., Grottker M., Lange J., 1997 Sustainable water and waste management in urban areas. Water Science and Technology 35(9:121-133.

[12] Salomon H., 1907. Die städtische Abwässerbeseitigung in Deutschland. Gustav Fischer Verlag, Jena.

[13] Seeger H., 1999. The history of German waste water treatment. European Water Management 2(5:51-56.

[14] Stremme H. (jun.), 1942. Der Einfluss des Grundwassers auf die Bodenbildung des Heubuder Dünengebites. Beitrage zur Bodenforschung des Reichsgaues DanzigWestpreussen, 1:29.

[15] Wiebe E., 1865. Die Reinigung und Entwässerung der Stadt Danzig. Ernst u. Korn Verlag, Berlin.

[16] Woycicki K., 1956. Kanalizacja (Sewerage). BiA Warszawa (in Polish). 